\title{
Early onset esophageal adenocarcinoma: a distinct molecular entity?
}

\author{
Anna M.J. van Nistelrooij ${ }^{1,2}$, Ronald van Marion ${ }^{1}$, PALGA-group ${ }^{3}$, Katharina \\ Biermann$^{1}$, Manon C.W. Spaander ${ }^{4}$, J. Jan B. van Lanschot ${ }^{2}$, Bas P.L. Wijnhoven ${ }^{2}$ \\ and Winand N.M. Dinjens ${ }^{1}$ \\ ${ }^{1}$ Department of Pathology, Erasmus MC Cancer Institute, University Medical Center Rotterdam, The Netherlands \\ 2 Department of Surgery, Erasmus MC Cancer Institute, University Medical Center Rotterdam, The Netherlands \\ 3 Members of the PALGA-group: I. van Lijnschoten, Pathology and Medical Microbiology, PAMM Institute, Eindhoven, The \\ Netherlands. M. Hogenes, Laboratory of Pathology, Oost-Nederland, Hengelo, The Netherlands \\ ${ }^{4}$ Department of Gastroenterology and Hepatology, Erasmus MC Cancer Institute, University Medical Center Rotterdam, The \\ Netherlands
}

Correspondence to: Winand N.M. Dinjens, email: w.dinjens@erasmusmc.nl

Keywords: esophageal adenocarcinoma, early onset cancer, molecular analysis

Received: December 26,2015 Accepted: January 22, $2016 \quad$ Published: February 01, 2016

This is an open-access article distributed under the terms of the Creative Commons Attribution License, which permits unrestricted use, distribution, and reproduction in any medium, provided the original author and source are credited.

\section{ABSTRACT}

Esophageal adenocarcinoma (EAC) is typically diagnosed in elderly with a median age of 68 years. The incidence of EAC has been rising over the last decades, also among young adults. The aim of the study was to investigate whether early onset EAC is a distinct molecular entity.

To identify early onset EACs, the nationwide network and registry of histo- and cytopathology in the Netherlands (PALGA) was searched. Twenty-eight tumors of patients aged $\leq \mathbf{4 0}$ years were selected and matched with 27 tumors of patients aged $\geq 68$ years. DNA was isolated from surgically resected specimen and sequenced on the Ion Torrent Personal Genome Machine with the Ion AmpliSeq Cancer Panel.

No differences in mutational load between early onset and conventional EACs were observed $(P=0.196)$. The most frequently mutated genes were TP53 $(73 \%)$ and $P 16(16 \%)$. Additional mutations in early onset EACs occurred exclusively in: APC, CDH1, CTNNB1, FGFR2, and STK11. In the conventional EACs additional mutations were exclusively identified in: ABL1, FBXW7, GNA11, GNAS, KRAS, MET, SMAD4, and VHL.

Additional mutations besides TP53 and P16 seem to occur in different genes related to cell fate pathways for early onset EACs, while the additional mutations in conventional EACs are related to survival pathways.

\section{INTRODUCTION}

Esophageal adenocarcinoma (EAC) is typically diagnosed in elderly adults with a median age of 68 years [1]. The incidence of EAC has been rising rapidly over the last decades, also among young adults $[2,3]$. The clinicopathological characteristics of these young adults with early onset EACs are different compared to the conventional EAC of the older patients: those with early onset EAC suffer from less co-morbidities, present with advanced disease stages more often, undergo more aggressive treatments, but ultimately obtain the same relative five-year survival rates as their older counterparts [4-6]. Individuals can be predisposed to early onset EAC through heredity, since seven percent of the patients diagnosed with EAC can be considered Familial Barrett's Esophagus (FBE), of which the age at diagnosis is generally lower compared to sporadic cases [7,8], yet no genetic defects related to FBE have been identified. Nevertheless, early onset EAC can be sporadic as well, lacking a genetic predisposition.

It has been accepted that cancer is generally a 
disease of the elderly population. In addition, evidence is obtained that the transformation of a normal cell into a malignant cell and subsequently the outgrowth to a clinically manifest lesion takes several decades [9]. This transformation process is driven by genomic instability leading to the accumulation of mutations. About three mutations in driver genes, which are causally involved in the tumorigenic process, have to accumulate to induce this malignant transformation [10]. As a result of the genomic instability also passenger mutations, which are not involved in the tumorigenic process, will accumulate. Hence, it can be anticipated that early onset EACs went through an accelerated transformation process and as a result could have a lower mutational load of (passenger) mutations, as has been reported for other tumors before [11]. In addition, it is possible that early onset EAC is a distinct molecular entity as has been demonstrated e.g. for colorectal carcinoma [12].

The aim of the present study was to investigate whether early onset EAC is a distinct molecular entity. By next-generation sequencing with a standard cancer panel the mutational load and molecular profile of early onset EACs was determined and compared with the conventional EACs.

\section{RESULTS}

Thirty-seven patients diagnosed with EAC or adenocarcinoma of the gastro-esophageal junction (GEJ) and aged $\leq 40$ years at time of diagnosis were identified in the PALGA database. Twenty-eight samples obtained from these patients passed quality controls and were included in the study (mean age: 37.2 years, range $28-40$ years, $89 \%$ male). Twenty-seven patients diagnosed with EAC or adenocarcinoma of the GEJ and aged $\geq 68$ years at time of diagnosis were matched with patients aged $\leq 40$ years based on TNM-stage and tumor differentiation grade (Mean age: 74.6 years, range $68-83$ years, $78 \%$ male). All tumors were tested microsatellite stable. Of the patients aged $\leq 40$ years seven received some form of neoadjuvant therapy, while none of the patients aged $\geq 68$ years did. Patients- and tumor characteristics are listed in Table 1 according to age groups.

Next-Generation sequencing with the Ion Torrent Personal Genome Machine (PGM) revealed 83 mutations in 55 EAC samples before filtering: 36 mutations in the patients aged $\leq 40$ years and 47 mutations in the patients aged $\geq 68$ years $(P=0.094)$. After filtering 78 mutations remained: 35 mutations were identified in the patients

Table 1: Patient- and tumor characteristics according to age groups

\begin{tabular}{|c|c|c|c|}
\hline & $\begin{array}{l}\text { Early onset EAC } \\
n=28(\%)\end{array}$ & $\begin{array}{l}\text { Conventional EAC } \\
n=27(\%)\end{array}$ & $p$-value $\left(\chi^{2}\right)$ \\
\hline Mean Age (sd) & $37.21(3.023)$ & $74.63(4.395)$ & $<0.001$ ( $T$-test $)$ \\
\hline $\begin{array}{l}\text { Gender } \\
\text { Male } \\
\text { Female }\end{array}$ & $\begin{array}{l}25(89.3) \\
3(10.7)\end{array}$ & $\begin{array}{l}21(77.8) \\
6(22.2)\end{array}$ & 0.249 \\
\hline $\begin{array}{l}\text { Tumor type } \\
\text { EAC } \\
\text { GEJAC } \\
\text { Cardia } \\
\text { Unknown } \\
\end{array}$ & $\begin{array}{c}16(57.1) \\
9(32.1) \\
2(7.1) \\
1(3.6) \\
\end{array}$ & $\begin{array}{c}17(63.0) \\
9(33.3) \\
1(3.7) \\
0(0)\end{array}$ & 0.718 \\
\hline $\begin{array}{l}\text { TNM stage* } \\
\text { IA } \\
\text { IB } \\
\text { IIA } \\
\text { IIB } \\
\text { IIIA } \\
\text { IIIB } \\
\text { IIIC } \\
\text { IV } \\
\end{array}$ & $\begin{array}{c}5(17.9) \\
3(10.7) \\
0(0) \\
2(7.1) \\
9(32.1) \\
3(10.7) \\
5(17.9) \\
1(3.6) \\
\end{array}$ & $\begin{array}{c}3(11.1) \\
0(0) \\
1(3.7) \\
7(25.9) \\
7(25.9) \\
2(7.4) \\
6(22.2) \\
1(3.7) \\
\end{array}$ & 0.350 \\
\hline $\begin{array}{l}\text { Differentiation grade } \\
\text { High grade dysplasia } \\
\text { Good } \\
\text { Moderate } \\
\text { Poor } \\
\text { Unknown }\end{array}$ & $\begin{array}{l}0(3.6) \\
4(14.3) \\
11(39.3) \\
9(32.1) \\
4(14.3)\end{array}$ & $\begin{array}{c}0(0) \\
0(0) \\
16(59.3) \\
9(33.3) \\
2(7.4)\end{array}$ & 0.233 \\
\hline
\end{tabular}

$\mathrm{EAC}=$ esophageal adenocarcinoma

$\mathrm{GEJAC}=$ gastro-esophageal junction adenocarcinoma

*According to the classification of the American Joint Committee on Cancer (AJCC) Staging Manual $7^{\text {th }}$ edition. 
aged $\leq 40$ years and 43 mutations in the patients aged $\geq 68$ years. The mean number of mutations for the young adults and the older patients was, 1.25 (SD 0.844) and 1.59 (SD $1.083)$ respectively, and not significantly different $(P=$ 0.196).

The most frequently mutated genes were TP53 (73\%), P16 (16\%), ATM (7\%), and RB1 (7\%). In the early onset EACs TP53 was altered in $75 \%$ and $P 16$ in $11 \%$, whereas in the conventional EACs a mutation in TP53 was found in $70 \%$ and P16 was mutated in $22 \%$. Except for one, all $P 16$ mutations occurred simultaneously with a TP53 mutation. In $43 \%$ of the early onset EACs and in $33 \%$ of the conventional EACs no additional mutations besides a TP53 mutations or a P16 mutations were identified. The genes $A T M, J A K 3, P I K 3 C A$, and $R B 1$ were mutated equally between both groups. Additional mutations in five individual early onset EACs occurred exclusively in the genes: $A P C, C D H 1, C T N N B 1, F G F R 2$, and $S T K 11$. In the conventional EACs additional mutations were exclusively identified in the genes: $A B L 1, F B X W 7$, GNA11, GNAS, KRAS, MET, SMAD4, and VHL (Figure 1 and Table 2).

\section{DISCUSSION}

For the first time a molecular analysis was performed on an exclusive group of patients with early onset EACs, to determine whether this is a distinct entity based on molecular spectrum. In comparison with the conventional EACs no difference in the total mutational load, including common driver mutations, was observed in the early onset EACs. Although no evidently differences were observed between the two groups with regard to molecular profile, the additional mutations, besides mutations in TP53 and $P 16$, identified in some individual early onset EACs differed when compared to the additional mutations identified in the conventional EACs.

Presently, there is no accepted clear definition of early onset EACs. Recent publications demonstrate that $5 \%$ of the patients diagnosed with EAC are aged $\leq 40$ years [5] and $10 \%$ aged $\leq 50$ years [6]. In these studies young adults with EAC were compared with the conventional EAC patients, with a median age of 68 years, based on clinicopathological characteristics, showing that these younger patients present with more advanced disease stages, receive more often aggressive treatment regimes, however, ultimately obtain relative survival rates comparable with their older counterparts [6]. In order to ensure a clear segregation of the two entities and to avoid any overlap, a more restrictive definition of both early onset EAC and conventional EAC was used and patients between 41 and 67 years were excluded in the present study.

EAC evolves from the premalignant condition Barrett's esophagus, following a multimorphological pathway, in which metaplasia evolves to low-grade dysplasia, high-grade dysplasia and ultimately into invasive adenocarcinoma, during this malignant transformation mutations accumulate over time [9, 13]. The number of mutations in a tumor originating from self-renewing tissue, e.g. the esophagus, is directly correlated with age. The majority of these mutations are passenger mutations that have no effect on the neoplastic progression. Whereas, the minority are the driver mutations, which confer a selective growth advantage. The passenger mutations occur mostly during the preneoplastic phase, which is evidently longer for older patients than for the younger ones [14]. Based on this concept it can be hypothesized that the number of total mutations, i.e. mutational load, is lower in early onset

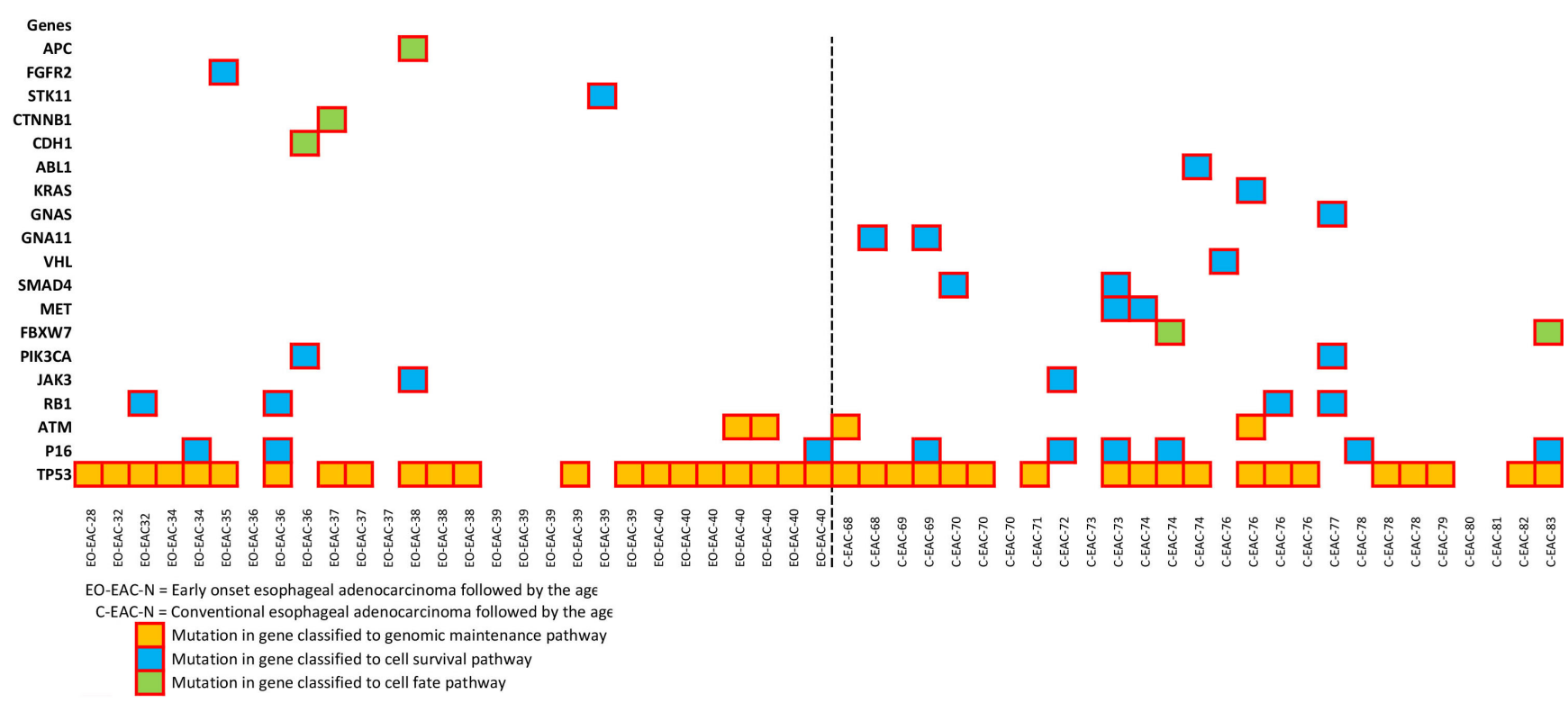

Figure 1: Mutations identified in early onset EACs and conventional EACs classified to cell signaling pathways. 
Table 2: Extensive information of classification of genes in signaling pathways and cellular processes according to age groups.

\begin{tabular}{|c|c|c|c|c|c|}
\hline Gene & Gene Name & \begin{tabular}{|l|} 
Early onset/ \\
Conventional \\
\end{tabular} & Classification & $\begin{array}{l}\text { Core } \\
\text { pathway }\end{array}$ & $\begin{array}{l}\text { Cellular } \\
\text { process }\end{array}$ \\
\hline$A B L 1$ & $\begin{array}{l}\text { C-abl oncogene } 1, \\
\text { non-receptor tyrosine kinase }\end{array}$ & Conventional & Oncogene & $\begin{array}{l}\text { Cell Cycle/ } \\
\text { Apoptosis }\end{array}$ & Cell Survival \\
\hline$A P C$ & Adenomatous polyposis coli & Early onset & Tumor suppressor gene & APC & Cell Fate \\
\hline ATM & Ataxia telangiectasia mutated & $\begin{array}{l}\text { Early onset/ } \\
\text { Conventional }\end{array}$ & Tumor suppressor gene & $\begin{array}{l}\text { DNA } \\
\text { Damage } \\
\text { Control }\end{array}$ & $\begin{array}{l}\text { Genome } \\
\text { Maintenance }\end{array}$ \\
\hline $\mathrm{CDH1}$ & $\begin{array}{l}\text { Cadherin 1, type 1, } \\
\text { E-cadherin (epithelial) }\end{array}$ & Early onset & Tumor suppressor gene & APC & Cell Fate \\
\hline$C T N N B 1$ & $\begin{array}{l}\text { Catenin (cadherin-associated protein), } \\
\text { beta } 1,88 \mathrm{kDa}\end{array}$ & Early onset & Oncogene & APC & Cell Fate \\
\hline$F B X W 7$ & $\begin{array}{l}\text { F-box and WD repeat domain containing } \\
7\end{array}$ & Conventional & Tumor suppressor gene & $\mathrm{NOTCH}$ & Cell Fate \\
\hline FGFR2 & Fibroblast growth factor receptor 2 & Early onset & Oncogene & $\begin{array}{l}\text { PI3K; RAS } \\
\text {; STAT }\end{array}$ & Cell Survival \\
\hline GNA11 & $\begin{array}{l}\text { Guanine nucleotide binding protein } \\
\text { (G protein), alpha } 11 \text { (Gq class) }\end{array}$ & Conventional & Oncogene & $\begin{array}{l}\text { PI3K; } \\
\text { RAS; } \\
\text { MAPK }\end{array}$ & Cell Survival \\
\hline$G N A S$ & GNAS complex locus & Conventional & Oncogene & $\begin{array}{l}\text { APC; } \\
\text { PI3K; } \\
\text { TGF- } \beta \text {, } \\
\text { RAS }\end{array}$ & $\begin{array}{l}\text { Cell Survival/ } \\
\text { Cell Fate }\end{array}$ \\
\hline$J A K 3$ & Janus kinase 3 & $\begin{array}{l}\text { Early onset/ } \\
\text { Conventional } \\
\end{array}$ & Oncogene & STAT & Cell Survival \\
\hline$K R A S$ & $\begin{array}{l}\text { v-Ki-ras2 Kirsten rat sarcoma viral } \\
\text { oncogene homolog }\end{array}$ & Conventional & Oncogene & RAS & Cell Survival \\
\hline$M E T$ & $\begin{array}{l}\text { Met proto-oncogene (hepatocyte growth } \\
\text { factor receptor) }\end{array}$ & Conventional & Oncogene & PI3K; RAS & Cell Survival \\
\hline P16 & Cyclin-dependent kinase inhibitor $2 \mathrm{~A}$ & $\begin{array}{l}\text { Early onset/ } \\
\text { Conventional }\end{array}$ & Tumor suppressor gene & $\begin{array}{l}\text { Cell Cycle/ } \\
\text { Apoptosis }\end{array}$ & Cell Survival \\
\hline PIK3CA & $\begin{array}{l}\text { Phosphatidylinositol-4,5-Bisphosphate } \\
\text { 3-Kinase, catalytic subunit alpha }\end{array}$ & $\begin{array}{l}\text { Early onset/ } \\
\text { Conventional }\end{array}$ & Oncogene & PI3K & Cell Survival \\
\hline$R B 1$ & Retinoblastoma 1 & $\begin{array}{l}\text { Early onset/ } \\
\text { Conventional } \\
\end{array}$ & Tumor suppressor gene & $\begin{array}{l}\text { Cell Cycle/ } \\
\text { Apoptosis }\end{array}$ & Cell Survival \\
\hline SMAD4 & SMAD family member 4 & Conventional & Tumor suppressor gene & TGF- $\beta$ & Cell Survival \\
\hline STK11 & Serine/threonine kinase 11 & Early onset & Tumor suppressor gene & mTOR & Cell Survival \\
\hline TP53 & Tumor protein p53 & $\begin{array}{l}\text { Early onset/ } \\
\text { Conventional }\end{array}$ & Tumor suppressor gene & $\begin{array}{l}\text { Cell Cycle/ } \\
\text { Apoptosis; } \\
\text { DNA } \\
\text { Damage } \\
\text { Control } \\
\end{array}$ & $\begin{array}{l}\text { Genome } \\
\text { Maintenance }\end{array}$ \\
\hline$V H L$ & Von Hippel-Lindau tumor suppressor & Conventional & Tumor suppressor gene & $\begin{array}{l}\text { PI3K; } \\
\text { RAS; } \\
\text { STAT }\end{array}$ & Cell Survival \\
\hline
\end{tabular}

Adapted from Vogelstein et al. 2013 [9]

EACs as compared to conventional EACs.

Although it did not reached the level of significance, probably due to the relatively small amount of patients, a higher amount of total mutations (i.e. passenger and driver mutations) was observed in the conventional EACs when compared to the early onset EACs, which is in line with concept as has been described previously. The current data did not revealed a significant difference in the load of driver mutations between the two age groups. Since the use of the Cancer Hotspot panel in this study, by which only 207 gene "hot spot" regions are investigated that are frequently mutated in human cancers, not all genes were covered. Hence, a complete overview of the total mutation spectrum per patient could not be established. An alternative explanation for the comparable load of mutations between the early onset 
EACs and the conventional EACs can be the occurrence of an ultramutator phenotype in the young adults resulting in an accelerated accumulation of mutations. By this phenomenon, young adults with early onset EAC could bear a comparable mutational load as compared to their older counterparts despite their shorter time of tumorigenesis [15].

At a first glance no evidently differences were observed between the early onset EACs and the conventional EACs, with regard to the molecular profiles: the tumor suppressor gene TP53 was altered in approximately $72 \%$ of EACs $(75 \%$ in early onset $v s .70 \%$ in conventional EACs), which is comparable with other studies [16]. Mutations of TP53 have been suggested to be an early genetic event in the multimorphological pathway of esophageal adenocarcinogenesis and are facilitating the accumulation of mutations [9, 17]. Alterations of tumor suppressor gene P16 are additional early events in EAC, and present in approximately $12 \%$ [16]. Here, in $11 \%$ of the early onset EACs a P16 mutation was identified, whereas in the conventional EACs a $P 16$ mutation was identified in $22 \%$. A remarkable observation was made regarding the additional mutational spectrum; the genes $A P C, C D H 1, C T N N B 1, F G F R 2$, and STK11 were exclusively mutated in five individual early onset EACs. Whereas these mutations were not identified in the conventional EACs, that instead, exclusively carried additional mutations in the genes $A B L 1, F B X W 7$, GNA11, GNAS, KRAS, MET, SMAD4, and VHL. Since the additional mutations were identified in five individual early onset EACs it might be based on randomness. In addition, in a large whole exome sequencing study on EACs performed by Dulak et al. mutations in $A P C$, $C D H 1, C T N N B 1, F G F R 2$, and $S T K 11$ were identified in EAC patients, here categorized as conventional EAC of older patients (range: $51-85$ years), although in very small amounts [16].

However, considering the classification of cancer cell signaling pathways i.e. cell fate, cell survival, and genome maintenance, it is striking that the additional mutations in the early onset EACs occurred mainly in genes classified in cell fate pathways $(A P C, C D H 1$, $C T N N B$ 1), while all additional mutations in conventional EACs were identified in genes classified in survival pathways (ABL1, GNA11, KRAS, MET, SMAD4, VHL, $G N A S$, $F B X W 7)$. In addition, the shared mutations occurred in genes classified in genome maintenance pathways (TP53, ATM) as well as in survival pathways (JAK3, PIK3CA, P16). Mutations classified in cell fate pathways disturb the balance between differentiation and division, favoring the latter, which causes a selective growth advantage. Mutations categorized in cell survival pathways allow cancer cells to proliferate under limiting nutrient concentrations, making them survive in environments in which sister cells cannot [9]. Different biological pathways for patients with early onset cancers have been described earlier, for example in breast cancer, colorectal cancer, melanoma, and tongue cancer [18].

Taken together, these findings indicate that the development of EAC requires, regardless of the age of onset, a TP53 mutation mostly accompanied by a P16 mutation. However, the additional mutations needed to probably induce the malignant transformation [10] in some early onset EACs seem to occur in different genes, related to different pathways, as compared to the additional mutated genes in conventional EACs. From a treatment perspective, different pathways could indicate different inhibitors in the means of targeting treatment as has been established for metastatic colorectal cancer [19]. The current study gives a clue for a distinct molecular biology for early onset EAC. More extensive sequencing of larger cohorts of young adults and older patients with EAC have to be performed to determine whether early onset EAC is truly a distinct molecular entity that needs probably a different targeting therapy in the future.

\section{MATERIALS AND METHODS}

\section{Patient identification}

PALGA, the nationwide network and registry of histopathology and cytopathology, contains pathology reports generated in the Netherlands since 1971 and has complete national coverage since 1991 encompassing the pathology laboratories from all academic and nonacademic hospitals in the Netherlands [20]. The PALGA database was searched, with approval of their Privacy Commission and Scientific Council, to identify all patients diagnosed with an adenocarcinoma of the esophagus or the GEJ and aged $\leq 40$ years in the Netherlands. The following search terms were used: "primary carcinoma," "esophagus", "stomach," and "age $\leq 40$ years". The search was performed from January 1990 to March 2013. Cases were further confirmed or excluded after careful evaluation of the individual pathology reports.

The selected early onset EACs were compared with a group of conventional EACs collected from the Pathology archive of the Erasmus MC Cancer Institute, University Medical Center, Rotterdam. Patients aged $\geq 68$ years and diagnosed with an adenocarcinoma of the esophagus or GEJ for which an esophagectomy was performed were selected and matched with the patients with early onset EAC with regard to grade of tumor differentiation and TNM-stage (according to the classification of the American Joint Committee on Cancer (AJCC) Staging Manual $7^{\text {th }}$ edition) [21]. 


\section{Tissue samples}

Formalin fixed paraffin embedded (FFPE) tumor tissues were provided by the participating laboratories of PALGA. The tissue blocks were assessed anonymously according to the Proper Secondary Use of Human Tissue code established by the Dutch Federation of Medical Scientific Societies (http://www.federa.org). In addition the study was approved by The Medical Ethical Committee of the Erasmus MC Cancer institute, University Medical Center, Rotterdam.

Tumor tissue areas composed of at least $50 \%$ neoplastic cells (indicated by a GI-pathologist) were manually microdissected from 10 to 15 hematoxylinstained sections $(4 \mu \mathrm{m})$ of FFPE tissue blocks. DNA was extracted using proteinase $\mathrm{K}$ and 5\% Chelex 100 resin. To determine the presence of microsatellite instability analyses were performed with the MSI Analysis System, Version 1.2 (Promega, Madison, WI, USA).

\section{Next-generation sequencing}

Ion semiconductor sequencing on the PGM was performed with the Ion AmpliSeq Cancer Hotspot Panel on tumor DNA according to the manufacturer's protocols. In short, libraries were made using the Ion AmpliSeq Library Preparation Kit. A template was prepared using the Ion OneTouch Template Kit and sequencing was performed with the Ion Sequencing Kit v2.0 on an Ion 316 chip. Data were analyzed with the Variant Caller v2.2.3-31149 (Life Technologies, Carlsbad, CA, USA). Variants were called when the position was covered at least 100 times. Variants found in at least $25 \%$ of the called reads were considered reliable. Variants present in the ESP6500si or 1000genomes databases in $\geq 1 \%$ were excluded. Subsequently nonsynonymous somatic point mutations, insertions and deletions that change the protein amino acid sequence and splice site alterations were selected as driver mutations.

\section{Data analysis}

Early onset EAC was defined as patients diagnosed with $\mathrm{EAC}$ at the aged $\leq 40$ years. This group was compared with the group of patients aged $\geq 68$ years. Patient- and tumor characteristics were described using frequencies and percentages. Proportions were compared using $\chi^{2}$ test for categorical variables. Differences in the mean number of mutations between the age groups were tested using independent samples $T$-test. Two-sided $P$-values $<0.05$ were considered statistically significant for all analyses. Data analysis was performed with SPSS version 20.0 (SPSS, Chicago, IL, USA).

\section{ACKNOWLEDGMENTS}

This study was financially supported by the foundation Zabawas.

\section{CONFLICTS OF INTEREST}

None declared.

\section{REFERENCES}

1. Dikken JL, Lemmens VE, Wouters MW, Wijnhoven BP, Siersema PD, Nieuwenhuijzen GA, van Sandick JW, Cats A, Verheij M, Coebergh JW and van de Velde CJ. Increased incidence and survival for oesophageal cancer but not for gastric cardia cancer in the Netherlands. Eur J Cancer. 2012; 48:1624-1632.

2. Bosetti C, Levi F, Ferlay J, Garavello W, Lucchini F, Bertuccio P, Negri E and La Vecchia C. Trends in oesophageal cancer incidence and mortality in Europe. Int $\mathrm{J}$ Cancer. 2008; 122:1118-1129.

3. Brown LM, Devesa SS and Chow WH. Incidence of adenocarcinoma of the esophagus among white Americans by sex, stage, and age. J Natl Cancer Inst. 2008; 100:11841187.

4. Cen P, Banki F, Cheng L, Khalil K, Du XL, Fallon M, Amato RJ and Kaiser LR. Changes in age, stage distribution, and survival of patients with esophageal adenocarcinoma over three decades in the United States. Ann Surg Oncol. 2012; 19:1685-1691.

5. Oezcelik A, Ayazi S, DeMeester SR, Zehetner J, Abate E, Dunn J, Grant KS, Lipham JC, Hagen JA and DeMeester TR. Adenocarcinoma of the esophagus in the young. J Gastrointest Surg. 2013; 17:1032-1035.

6. van Nistelrooij AM, van Steenbergen LN, Spaander MC, Tilanus HW, van Lanschot JJ, Lemmens VE and Wijnhoven BP. Treatment and outcome of young patients with esophageal cancer in the Netherlands. J Surg Oncol. 2014; 109:561-566.

7. Ash S, Vaccaro BJ, Dabney MK, Chung WK, Lightdale $\mathrm{CJ}$ and Abrams JA. Comparison of endoscopic and clinical characteristics of patients with familial and sporadic Barrett's esophagus. Dig Dis Sci. 2011; 56:1702-1706.

8. Verbeek RE, Spittuler LF, Peute A, van Oijen MG, Ten Kate FJ, Vermeijden JR, Oberndorff A, van Baal JW and Siersema PD. Familial clustering of Barrett's esophagus and esophageal adenocarcinoma in a European cohort. Clin Gastroenterol Hepatol. 2014; 12:1656-1663 e1651.

9. Vogelstein B, Papadopoulos N, Velculescu VE, Zhou S, Diaz LA, Jr. and Kinzler KW. Cancer genome landscapes. Science. 2013; 339:1546-1558.

10. Tomasetti C, Marchionni L, Nowak MA, Parmigiani G and Vogelstein B. Only three driver gene mutations are required for the development of lung and colorectal cancers. Proc 
Natl Acad Sci U S A. 2015; 112:118-123.

11. Vijg J. Somatic mutations, genome mosaicism, cancer and aging. Curr Opin Genet Dev. 2014; 26:141-149.

12. Kirzin S, Marisa L, Guimbaud R, De Reynies A, Legrain M, Laurent-Puig P, Cordelier P, Pradere B, Bonnet D, Meggetto F, Portier G, Brousset P and Selves J. Sporadic earlyonset colorectal cancer is a specific sub-type of cancer: a morphological, molecular and genetics study. PLoS One. 2014; 9:e103159.

13. Jankowski JA, Wright NA, Meltzer SJ, Triadafilopoulos G, Geboes K, Casson AG, Kerr D and Young LS. Molecular evolution of the metaplasia-dysplasia-adenocarcinoma sequence in the esophagus. Am J Pathol. 1999; 154:965973.

14. Tomasetti C, Vogelstein B and Parmigiani G. Half or more of the somatic mutations in cancers of self-renewing tissues originate prior to tumor initiation. Proc Natl Acad Sci U S A. 2013; 110:1999-2004.

15. Shlien A, Campbell BB, de Borja R, Alexandrov LB, Merico D, Wedge D, Van Loo P, Tarpey PS, Coupland P, Behjati S, Pollett A, Lipman T, Heidari A, Deshmukh S, Avitzur N, Meier B, et al. Combined hereditary and somatic mutations of replication error repair genes result in rapid onset of ultra-hypermutated cancers. Nat Genet. 2015; 47:257-262.

16. Dulak AM, Stojanov P, Peng S, Lawrence MS, Fox C, Stewart C, Bandla S, Imamura Y, Schumacher SE, Shefler E, McKenna A, Carter SL, Cibulskis K, Sivachenko A, Saksena G, Voet D, et al. Exome and whole-genome sequencing of esophageal adenocarcinoma identifies recurrent driver events and mutational complexity. Nat Genet. 2013; 45:478-486.

17. Stachler MD, Taylor-Weiner A, Peng S, McKenna A, Agoston AT, Odze RD, Davison JM, Nason KS, Loda M, Leshchiner I, Stewart C, Stojanov P, Seepo S, Lawrence MS, Ferrer-Torres D, Lin J, et al. Paired exome analysis of Barrett's esophagus and adenocarcinoma. Nat Genet. 2015; 47:1047-1055.

18. Bleyer A, Barr R, Hayes-Lattin B, Thomas D, Ellis C, Anderson B, Biology, Clinical Trials Subgroups of the USNCIPRGiA and Young Adult O. The distinctive biology of cancer in adolescents and young adults. Nat Rev Cancer. 2008; 8:288-298.

19. Laurent-Puig P, Manceau G, Zucman-Rossi J and Blons H. Dual blockade of epidermal growth factor receptor-induced pathways: a new avenue to treat metastatic colorectal cancer. J Clin Oncol. 2012; 30:1550-1552.

20. Casparie M, Tiebosch AT, Burger G, Blauwgeers H, van de Pol A, van Krieken JH and Meijer GA. Pathology databanking and biobanking in The Netherlands, a central role for PALGA, the nationwide histopathology and cytopathology data network and archive. Cell Oncol. 2007; 29:19-24.

21. Edge SB and Compton CC. The American Joint Committee on Cancer: the 7th edition of the AJCC cancer staging manual and the future of TNM. Ann Surg Oncol. 2010; 17:1471-1474. 